\title{
Aplikasi Pengenalan Jenis Kupu-Kupu Langka Berbasis Augmented Reality
}

\author{
Ni Luh Putu Novi Ambariani, I Ketut Adi Purnawan, Kadek Suar Wibawa \\ Program Studi Teknologi Informasi, Fakultas Teknik, Universitas Udayana \\ Jalan Raya Bukit Jimbaran, Kabupaten Badung, Bali-Indonesia \\ e-mail: putunoviambariani@gmail.com, adipurnawan@unud.ac.id, suar wibawa@unud.ac.id
}

\begin{abstract}
Abstrak
Area hutan yang berkurang mengakibatkan beberapa populasi kupu-kupu menjadi langka dan informasi mengenai jenis kupu-kupu langka semakin sulit ditemukan. Informasi mengenai kupu-kupu langka biasanya berupa teks atau gambar, sehingga kurang menarik minat masyarakat. Kupu-kupu memiliki warna mencolok dan pola yang unik serta beragam pada sayapnya. Aplikasi Pengenalan Jenis Kupu-kupu Langka berbasis Augmented Reality digunakan sebagai media pembelajaran yang memvisualisasikan bentuk dan warna pada kupukupu langka dalam bentuk objek 3D, sehingga dapat menarik minat masyarakat dan diharapkan dapat mengajak masyarakat untuk ikut melestarikan lingkungan.Aplikasi dikembangkan menggunakan Vuforia Library, Vuforia API, dan Teknik Marker Base Tracking. Aplikasi berjalan secara dinamis, sehingga marker dan objek 3D dapat ditambah maupun dikurangi tanpa harus melakukan modifikasi terhadap kode program aplikasi. Hasil yang diperoleh berdasarkan kuesioner yang dilakukankepada murid kelas 4 SD yaitu pengetahuan tentang metamorfosis kupu-kupu dan jenis kupu-kupu langka meningkat sebesar $36 \%$ pada aspek peningkatan pengetahuan, 64\% untuk nilai sangat menarik pada aspek grafis aplikasi, $71 \%$ untuk nilai sangat menarik pada aspek rekayasa perangkat lunak, dan $81 \%$ untuk nilai sangat menarik pada aspek entertainment.
\end{abstract}

Kata Kunci: Kupu-Kupu, Augmented Reality, Animasi 3D, Marker Based Tracking

\begin{abstract}
Deforestation resulting in butterfly populations becoming endangered and the information regarding endangered butterfly unattainable. Endangered butterfly information constantly found as text or as image, it makes it unappealing to public. Butterfly has distinctive color, unique and diverse patterns on their wings. Augmented reality-based endangered butterfly species identification application used as learning medium which visualized shape and color on endangered butterfly in 3D form, so that it would appeal public savor and expected to urge public to conserve environment. Application is developed using Vuforia Library, Vuforia API, and Marker Base Tracking Techniques. The application runs dynamically, so that the marker and the 3D objects can be added or eliminated without modifying the application code. The result acquired is based on $4^{\text {th }}$ grade elementary, student knowledge on butterfly metamorphosis increased by $36 \%$ on increase knowledge aspect, $64 \%$ marked the application graphic is very appealing, $71 \%$ marked the software engineering very appealing and $81 \%$ marked the entertainment aspect very appealing.
\end{abstract}

Keywords: Butterfly, Augmented Reality, 3D Animation, Marker Based Tracking

\section{Pendahuluan}

Kupu-kupu merupakan serangga bertubuh ramping dengan antena kecil diujungnya. Kupu-kupu memiliki enam kaki, dan sayapnya terdiri dari empat ruas sayap. Kupu-kupu memiliki warna mencolok dan pola yang unik pada setiap sayapnya, namun tidak banyak orang yang memperhatikannya [1].Area hutan yang berkurang mengakibatkan beberapa populasi kupu-kupu menjadi langka[2] dan informasi mengenai jenis kupu-kupu langka semakin 
sulitditemukan. Informasi mengenai kupu-kupu langka biasanya berupa teks atau gambar, sehingga kurang menarik minat masyarakat khususnya siswa siswi sekolah dasar. Media pembelajaran yang mampu memvisualisasikan bentuk dan warna kupu-kupu langkadalam bentuk 3D diperlukan,sehingga dapat menarik minat masyarakat dan diharapkan dapat mengajak masyarakat untuk ikut melestarikan lingkungan.

Pengenalan jenis kupu-kupu langka dapat dilakukan dengan menggunakan Teknologi Augmented Reality.Augmented Reality (AR) adalah suatu teknologi yang menggabungkan benda dua dimensi dan tiga dimensi ke dalam sebuah lingkungan nyata lalu memvisualisasikan benda-benda tersebut dalam waktu nyata[3]. Augmented realitysudah diterapkan dalam beberapa penelitian, salah satunya adalah penelitian dengan judul "Application of Basic Balinese Dance Using Augmented Reality on Android" oleh Ni Putu Sinria Franza, pada Tahun 2016. Tujuan dari Aplikasi Balinese Danceadalah membuat orang-orang agar tertarik belajar Tari Bali. Pengguna Aplikasi Balinese Dance, sebagian besar memberikan pendapat yang baik $(60 \%-70 \%)$. Pengguna yang menguji aplikasi ini sangat tertarik dan antusias ketika 3D muncul dan bergerak[4], sehinggaaugmented reality cocok digunakan sebagai media pengenalan atau pembelajaran. Kekurangan dari pengimplementasian augmented reality pada Aplikasi Balinese Dance yaitu masih menggunakan augmented reality statis.

Penelitian lainnya dengan judul "Aplikasi Augmented Reality Magic Book Pengenalan Binatang untuk Siswa TK" oleh I Dewa Gede Wahya Dhiyatmika, pada Tahun 2015. Penelitian ini dikembangkan berbasis Android dengan menggunakan marker yang telah teridentifikasi objek 3D binatang, serta suara dan informasi dari binatang tersebut. Aplikasi Augmented Reality Magic Book Pengenalan Binatang untuk Siswa TK menggunakan Teknologi Augmented Reality[3]. Pengenalan jenis-jenis binatang kepada anak menjadi lebih mudah dan menarik karena aplikasi ini dapat menampilkan objek 3D dari binatang beserta suaranya dan penyajiannya lebih inovatif dengan menggunakan smartphone.

Kelebihanaugmented reality sebagai media pembelajaran dan kekurangan dari penelitian sebelumnya melatarbelakangi perancangan "Aplikasi Pengenalan Jenis Kupu-Kupu Langka Berbasis Augmented Reality". Aplikasi Pengenalan Jenis Kupu-Kupu Langka Berbasis Augmented Reality dikembangkan menggunakan Vuforia Library, Vuforia API, dan Teknik MarkerBase Tracking. Jenis kupu-kupu langka dapat bertambah maupun berkurang, sehingga sistem yang dinamis mampu mempermudah dalam proses menambahkan maupun mengurangi data kupu-kupu langka tanpa harus memodifikasi kode program pada aplikasi.Pengimplementasian Teknologi Augmented Realitydapat menjadi sebuahalternatif dalam memvisualisasikanjenis kupu-kupu langka dengan lebih mudah dan inovatif melalui objek 3D.

\section{Metodologi Penelitian}

Metodologi penelitian dapat diilustrasikan dengan gambaran umum. Gambaran umum menggambarkan keseluruhan alur proses dalam suatu aplikasi atau sistem. Gambaran umum dari Aplikasi Pengenalan Jenis Kupu-Kupu Langka berbasis Augmented Reality dapat diilustrasikan seperti pada Gambar 1. 


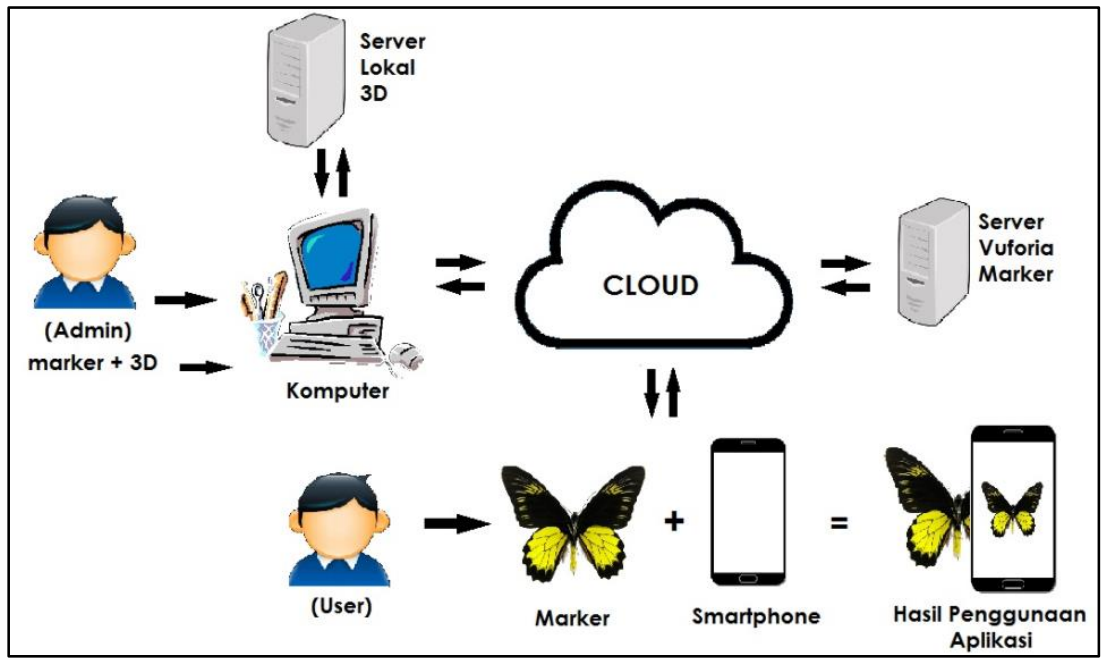

Gambar 1.Gambaran Umum Aplikasi

Gambaran umum aplikasi pada Gambar 1 menggambarkan penggunaan aplikasi secara umum. Aplikasi Web AR Kupu-Kupu dikembangkan menggunakan Vuforia API, sedangkan Aplikasi AR Kupu-Kupu dikembangkan menggunakan Vuforia Library. Pengguna dibagi menjadi dua, yaitu admin dan user.Admin mengakses Web AR Kupu-Kupu menggunakan komputer untuk melakukan manage data. Admin dapat malakukan proses managedata seperti menambah data, mengubah data, dan atau menghapus data. Data tersimpan ke dalam dua server, yaitu server Vuforia untuk menyimpan marker, dan server lokal untuk menyimpan animasi 3D. User dapat menggunakan aplikasi dengan smartphone yang telah ter-install Aplikasi AR Kupu-Kupu. User mengarahkan kamera smartphone ke marker untuk dideteksi. Sistem melakukan pengecekan marker pada server Vuforia, dan mengambil animasi 3D pada server lokal. Animasi 3D ditampilkan diatas marker yang telah terdeteksi.

\subsection{Use case Diagram}

Use case diagram digunakan untuk menggambarkan fitur-fitur yang dapat dijalankan pada aplikasi. Use case diagram dibagi menjadi dua, yaitu use case diagram user dan usecase diagram admin. Use case diagramuserpada Aplikasi Pengenalan Jenis Kupu-Kupu Langka berbasis Augmented Realitydapat diilustrasikan seperti pada Gambar 2.

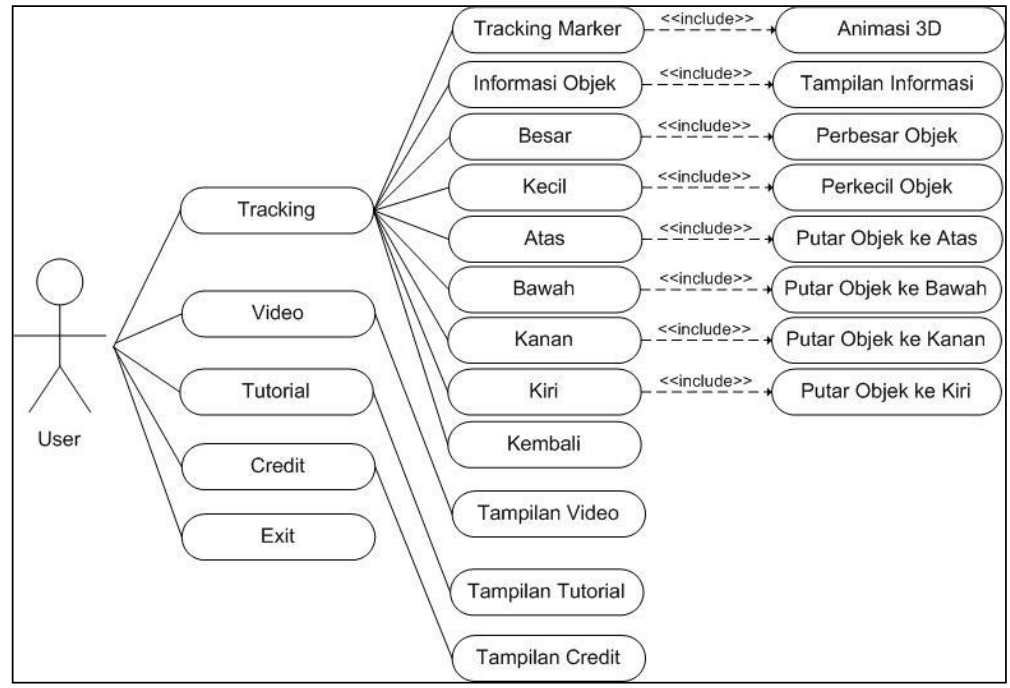




\section{Gambar 2.Use CaseDiagram(User)}

Use case diagram (user) pada Gambar 2 menggambarkan fitur-fitur yang dapat dijalankan user. Fitur utama aplikasi adalah tracking marker. Tracking marker merupakan proses mendeteksi marker untuk menampilkan animasi 3D dari objek pada marker tersebut. Trackingmarker memiliki fitur seperti informasi objek, memperbesar, memperkecil, putar kanan, putar kiri, putar atas, putar bawah, dan kembali. Video digunakan untuk menampilkan video metamorfosis kupu-kupu. Tutorial digunakan untuk menampilkan informasi penggunaan aplikasi. Credit digunakan untuk menampilkan informasi mengenai pembuat aplikasi. Exit digunakan untuk keluar dari Aplikasi Pengenalan Jenis Kupu-Kupu Langka berbasis Augmented Reality.

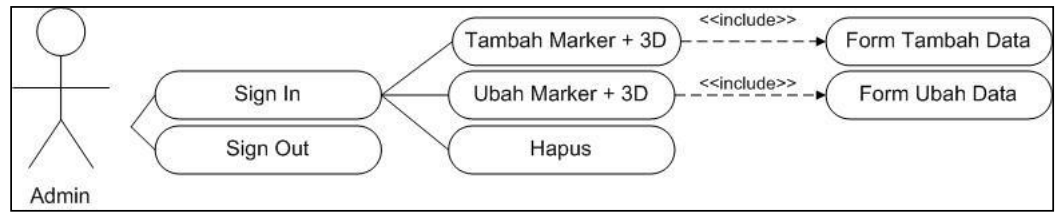

Gambar 3.Use CaseDiagram(Admin)

Use case diagram (admin) padaGambar3menggambarkan fitur-fitur yang terdapat digunakan oleh admin. Admin dapat masuk ke dalam sistem dengan melakukan sign in, mengelola data marker dan animasi 3D dengan fitur tambah, ubah, dan hapus. Admin melakukan sign out untuk keluar dari aplikasi.

\section{Kajian Pustaka}

Kajian pustaka merupakan subbagian untuk memaparkan semua pustaka yang digunakan sebagai acuan dalam penelitian.

\subsection{Kupu-Kupu}

Kupu-kupu adalah kelompok serangga yang melakukan metamorfosis sempurna dengan melewati siklus hidup sebagai telur, larva, pupa, dan imago. Kupu-kupu dengan mudah dapat ditemukan pada kawasan hutan, jalan setapak di pinggir hutan, dan sepanjang aliran sungai. Kupu-kupu memiliki peranan yang penting dalam suatu ekosistem. Kupu-kupu dapat membantu penyerbukan pada tanaman-tanaman berbunga [1].

\subsection{Augmented Reality}

Augmented Reality adalah teknologi yang menggabungkan benda maya dua dimensi dan ataupun tiga dimensi ke dalam sebuah lingkungan nyata,kemudian diproyeksikan ke dalam waktu nyata. Benda-benda maya yang diproyeksikan ke dalam waktu yang nyata berfungsi untuk menampilkan informasi, sehingga augmented realitydapat digunakan sebagai alat untuk membantu persepsi dan interaksi penggunanya dengan dunia nyata[3].

Penelitian yang membahas tentang penggunaan augmented reality yaitupenelitian dengan judul "Augmented Reality for Chemical Elements: Periodikar" oleh A. A. K. Oka Sudana, pada Tahun 2016. Marker dan video animasi pada aplikasi dapat ditambahkan atau dikurangi tanpa memodifikasi kode program pada aplikasi. Penyimpanan marker dan penyimpanan video animasi ditempatkan pada dua server yang berbeda [5].

Penelitian lainnya yang membahas augmented realityyaitu "Augmented Reality Mobile Application of Balinese Hindu Temples: DewataAR" oleh Adi Ferliyanto Waruwu, pada Tahun 2015. Aplikasi DewataAR dibuat menggunakan library Vuforia dengan Teknik Marker Base Tracking. Aplikasi bekerja dengan memindai brosur obyek wisata menggunakan smartphone Android atau tablet, untuk menampilkan informasi objek-objek pariwisata[6].

\section{3. $\quad$ Marker Based Tracking}

Marker yang digunakan harus cenderung memiliki warna kontras untuk mendapatkan rating terbaik. Marker yang buruk sulit dideteksi device atau bahkan tidak bekerja [7]. Marker 
based tracking adalah AR yang bekerja dengan menggunakan marker atau penanda objek dua dimensi yang memiliki suatu pola dan dibaca komputer melalui kamera [8].

\subsection{Unity}

Unity merupakan salah satu game engine dengan lisensi source proprietary, namun lisensi pengembangannya dibagi menjadi 2 bagian, yaitu free (gratis) dan berbayar sesuai perangkat target pengembangan aplikasi.Unityeditor menyediakan peralatan yang dapat digunakan untuk mempermudah pengembangan aplikasi yaitu Unity Tree dan Terrain Creatorseperti mempermudah pembuatan vegetasi dan terrain serta MonoDevelop untuk proses pemrograman[9].

\subsection{Vuforia}

Vuforia merupakan software library untuk membuat sebuah aplikasi augmented reality, yang menggunakan sumber yang konsisten dengancomputer vision yang fokus pada image recognition. Vuforia memiliki beberapa fitur dan kemampuan, yang dapat membantu pengembang dalam mewujudkan pemikiran, tanpa adanya batas secara teknikal. Platform Vuforia mendukung pengembang untuk menghasilkan aplikasi yang dapat digunakan pada sebagian besar jenis smartphone[10].

\section{Hasil dan Pembahasan}

Hasil dan pembahasan merupakan bagian untuk menjelaskan mengenai aplikasi yang dihasilkan berdasarkan rancangan aplikasi.

\subsection{Tampilan Aplikasi AR Kupu-Kupu}

Aplikasi AR Kupu-Kupu digunakan oleh user untuk menampilkandata kupu-kupu langka. Pengujian dilakukan dengan menjalankan fitur-fitur yang dapat digunakan oleh user. Tampilan uji coba pada Aplikasi AR Kupu-Kupu dapat dilihat pada Gambar 4.

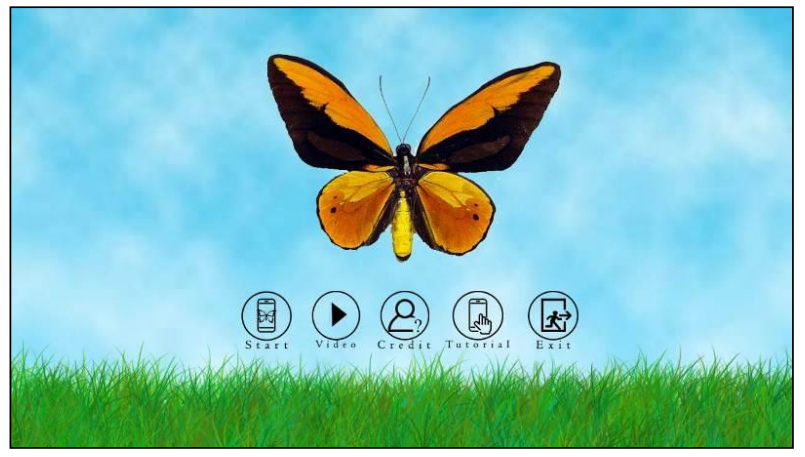

Gambar 4.Tampilan Menu

Tampilan menu pada Gambar4merupakan scene utama yang digunakan sebagai pintu masuk ke dalam scene yang berbeda-beda. Tombol yang terdapat pada scene menu berjumlah lima buah. Tombol Start digunakan untuk tracking marker. Tombol Tutorial digunakan untuk masuk ke dalam Scene Tutorial. Tombol Credit digunakan untuk masuk ke Scene Credit. Tombol Video digunakan untuk masuk ke Scene Video. Tombol Exit digunakan untuk keluar dari aplikasi. 


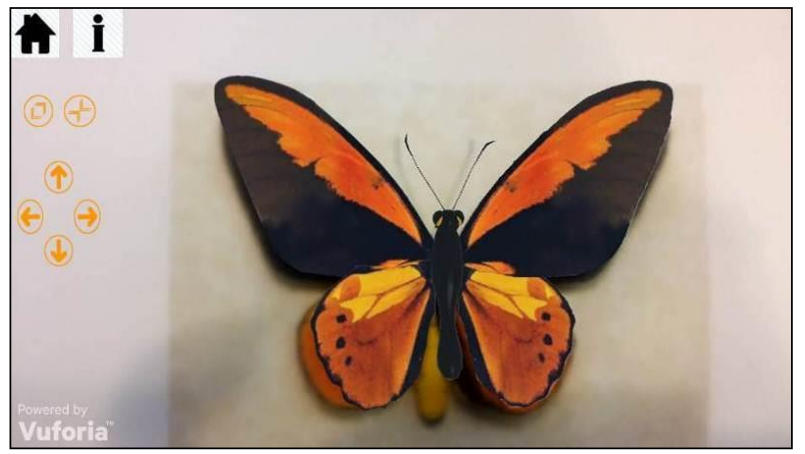

Gambar 5.Tampilan Tracking Marker

Tampilantracking marker padaGambar5digunakan untuk mendeteksi marker dan menampilkan animasi 3D. Scene Tracking memiliki fitur yang terdiri dari beberapa buah tombol.Tombol Home digunakan untuk kembali pada Scene Menu. Tombol Informasi digunakan untuk menampilkan informasi dari kupu-kupu yang dideteksi. Fitur zoom terdiri dari dua buah Tombol yaitu Tombol Perbesar dan Tombol Perkecil. Fitur Rotate terdiri dari empat buah Tombol yaitu Tombol Atas, Tombol Bawah, Tombol Kanan, dan Tombol Kiri.

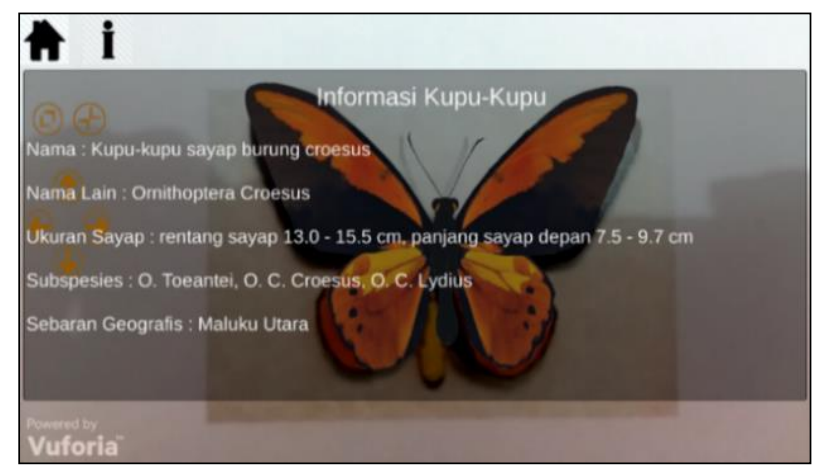

Gambar 6.Tampilan Informasi Objek

Tampilan informasipada Gambar6merupakan tampilan dari fitur informasi dengan memilih tombol dengan lambang "i". Informasi yang ditampilkan berupa nama, nama lain atau nama latin, ukuran sayap, subspesies, dan sebaran geografis dari jenis kupu-kupu yang ditampilkan.

\subsection{Tampilan Web AR Kupu-Kupu}

Web AR Kupu-Kupu digunakan oleh admin untuk melakukan manage data.Pengujian dilakukan dengan menjalankan fitur-fitur yang dapat digunakan oleh admin. Tampilan uji coba pada Aplikasi Web AR Kupu-Kupu dapat dilihat pada Gambar 8. 


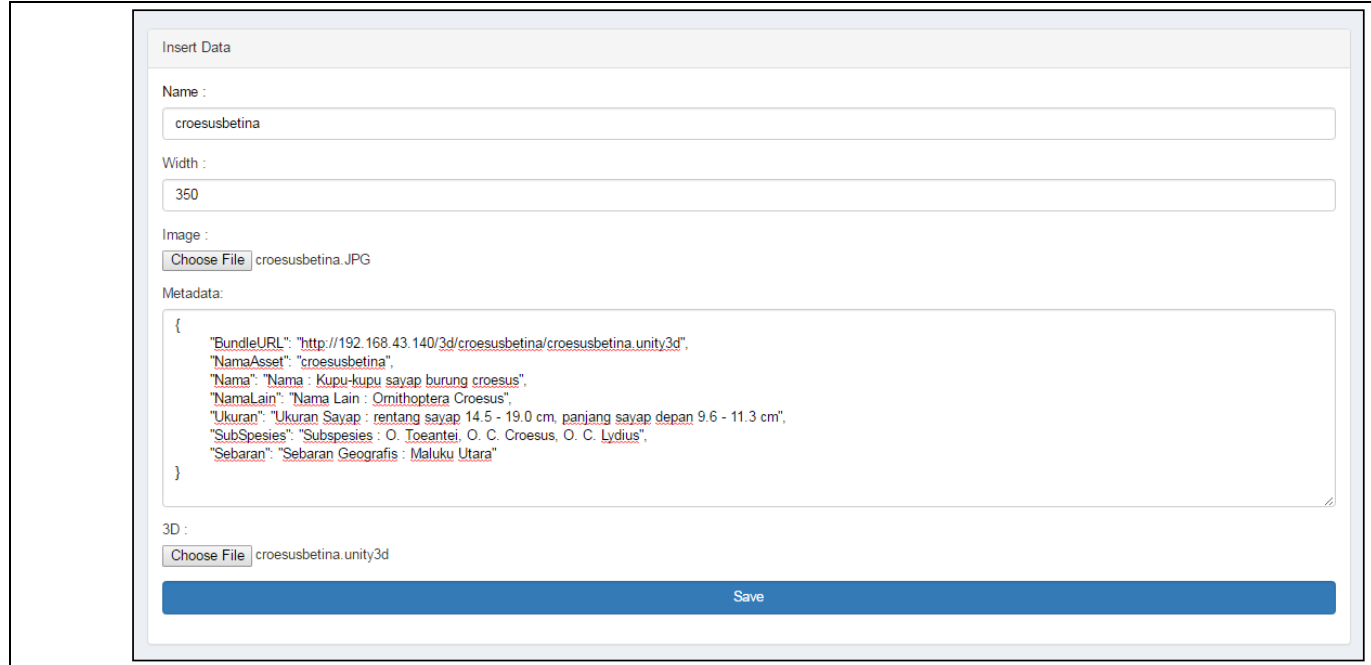

(a)

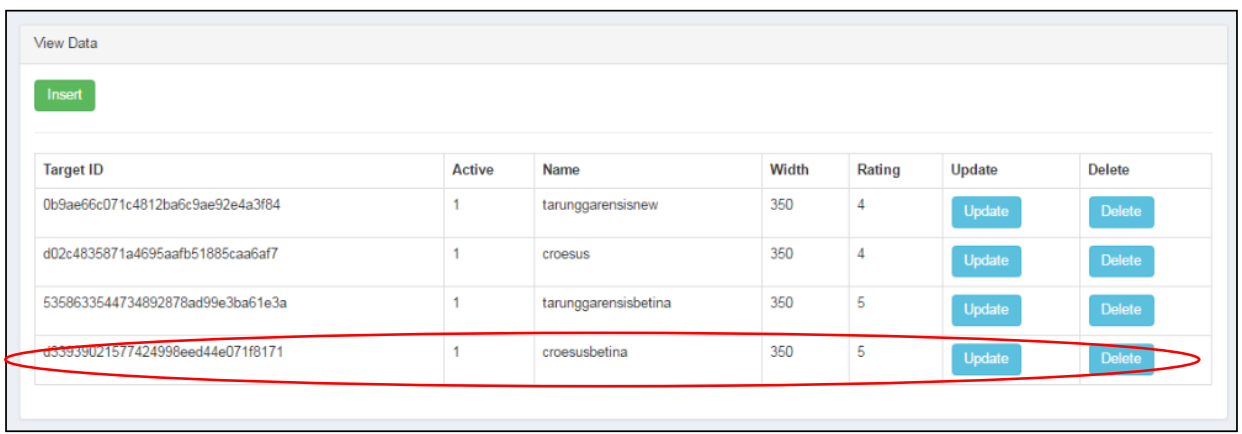

(b)

Gambar 7.(a)form insert data (b) form view data

Uji coba insert data pada Gambar7 merupakan tampilan dari proses insert data yang dilakukan oleh admin. Gambar 7(a) menampilkan form insert data yang telah terisi data untuk disimpan ke server. Data yang perlu diisi, yaitu Name, Width, Image, Metadata, dan 3D. Proses menyimpan data dapat dilakukan dengan menekan Button Save. Data yang tersimpan, ditampilkan pada Halaman View Data. Gambar $7(b)$ adalah tampilan data yang tersimpan.Gambar7(b)menampilkan data yang telah diisi sebelumnya berhasil tersimpan. Data yang tersimpan, dapat di-update atau di-deleteoleh admin. 


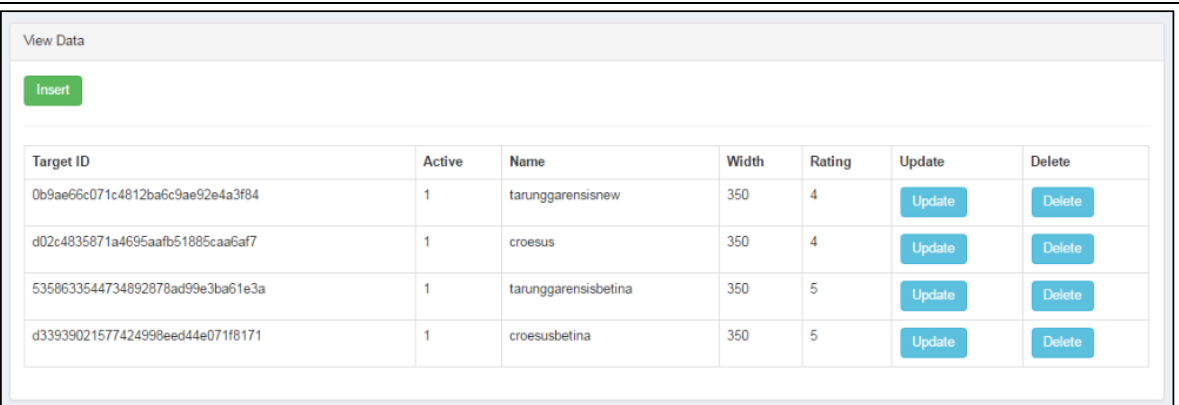

(a)

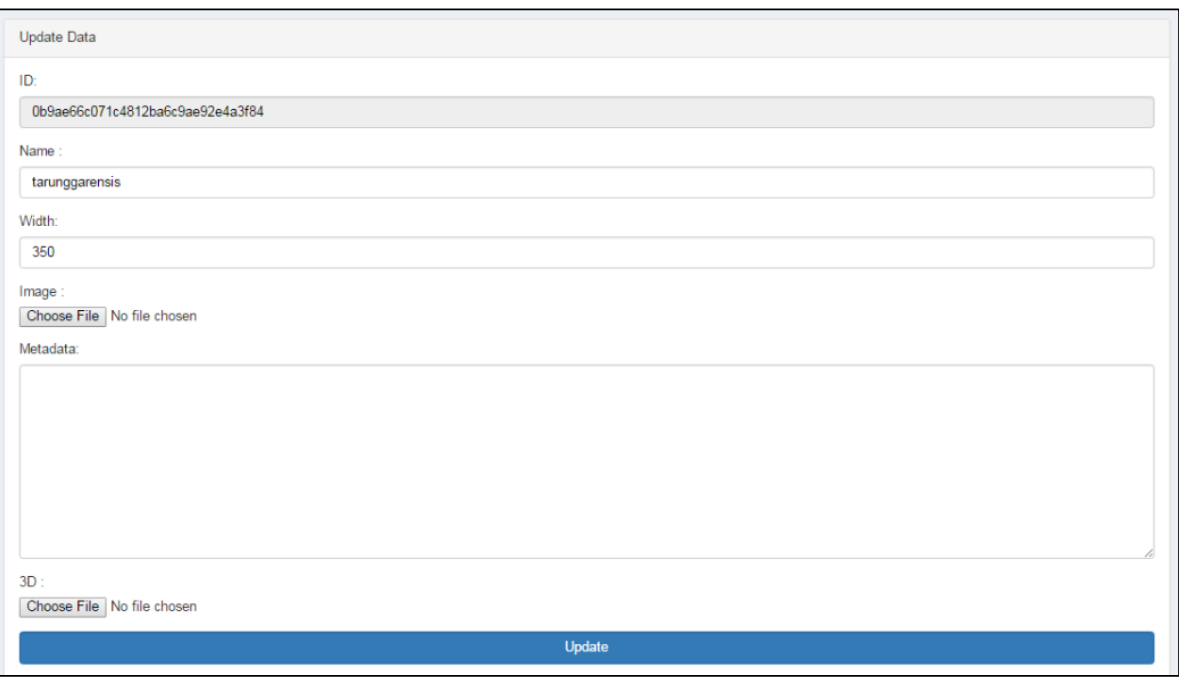

(b)

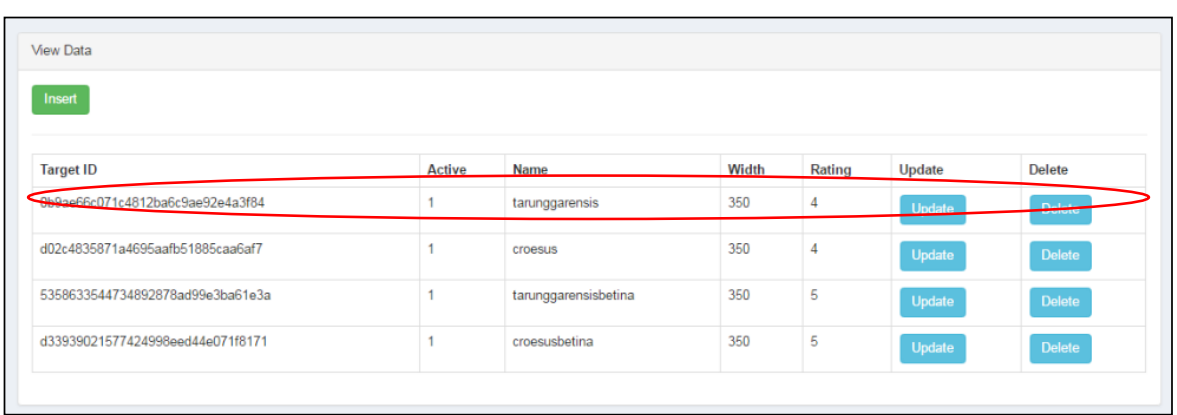

(c)

Gambar 8.(a)form view data (b) form update data (c) form view data setelah update

Gambar 8 mengilustrasikan proses update data yang dilakukan oleh admin dengan mengubah nama pada data yang tersimpan di server. Gambar 8(a) menampilkan data sebelum di-update pada Halaman View Data. Data yang tersimpan berjumlah empat buah data. Data yang diubah dalam pengujian adalah data tarunggarensisnew. Gambar 8(b) menampilkan form update data. Data yang di-update adalah Field Name dari tarunggarensisnew menjadi tarunggarensis. Gambar 8(c) menampilkan data yang telah di-update. Field Name dengan data tarunggarensisnew berhasil di-update menjadi tarunggarensis. Data ter-update, ditampilkan pada Gambar 8(c). 


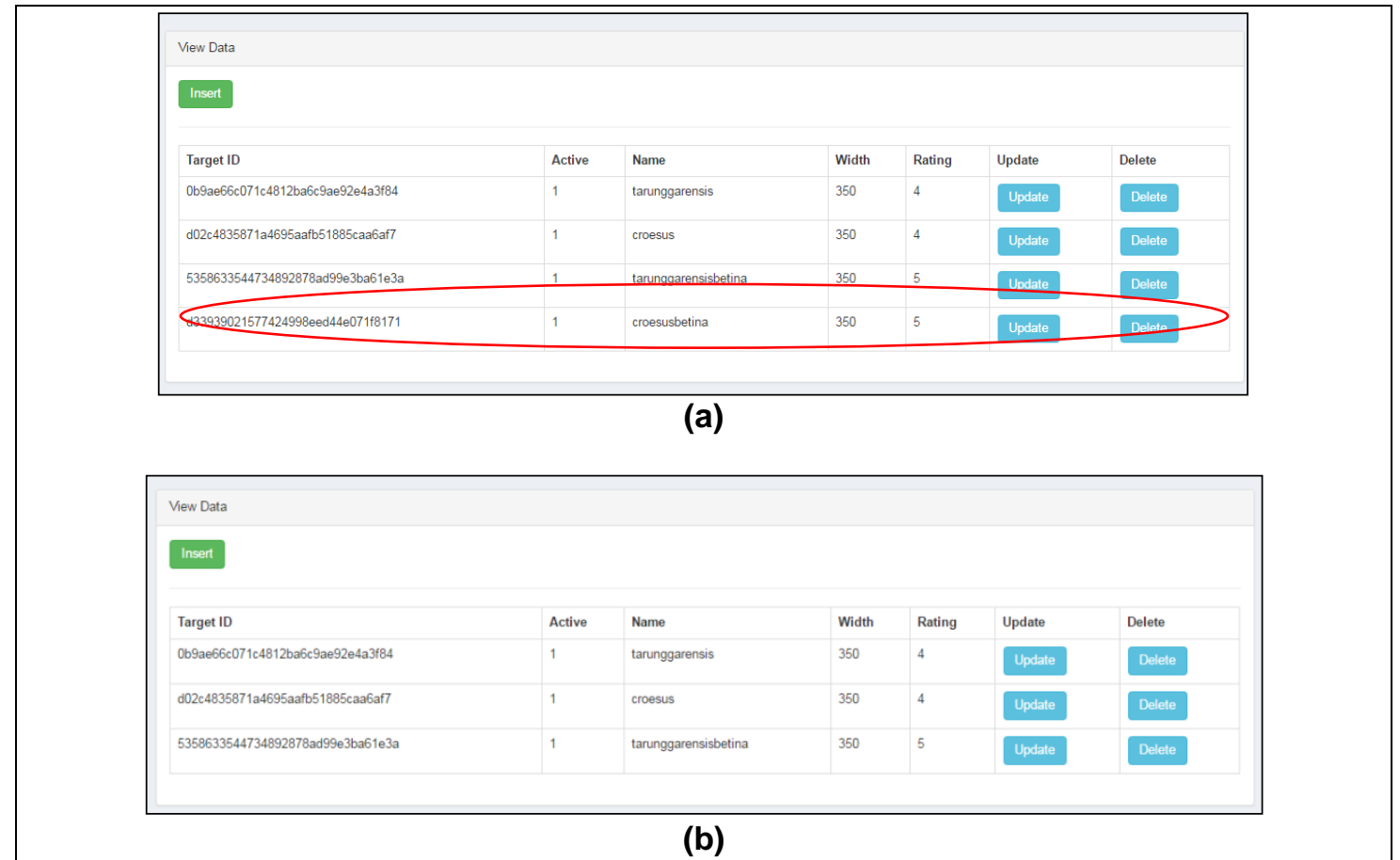

Gambar 9.(a) Form View Data Sebelum Delete (b) Form View Data Setelah Delete

Gambar 9 mengilustrasikan proses delete yang dilakukan oleh admin pada data yang tersimpan di server. Gambar9(a) menampilkan data yang tersimpan pada server. Uji coba yang dilakukan adalah delete data pada data croesusbetina. Jumlah data yang tersimpan adalah empat buah data. Data ter-update, ditampilkan pada Gambar 9(a). Gambar9(b) merupakan gambar yang menampilkan data terbaru. Data croesusbetina sudah tidak ada pada list data pada Gambar 9(b). Jumlah data tersimpan menjadi tiga buah data. Gambar 9(b) menunjukkan bahwa data berhasil dihapus.

\subsection{Penilaian Aplikasi}

Penilaian dilakukan oleh 31 orang siswa siswi kelas 4 sekolah dasar dengan mengisi kuesioner yang dibagikan. Kuesioner yang digunakan terbagi ke dalam 4 buah aspek, yaitu aspek peningkatan pengetahuan pengguna, aspek grafis aplikasi, aspek rekayasa perangkat lunak, dan aspek entertainment. Aspek peningkatan pengetahuan pengguna dapat dilihat pada Gambar 15.

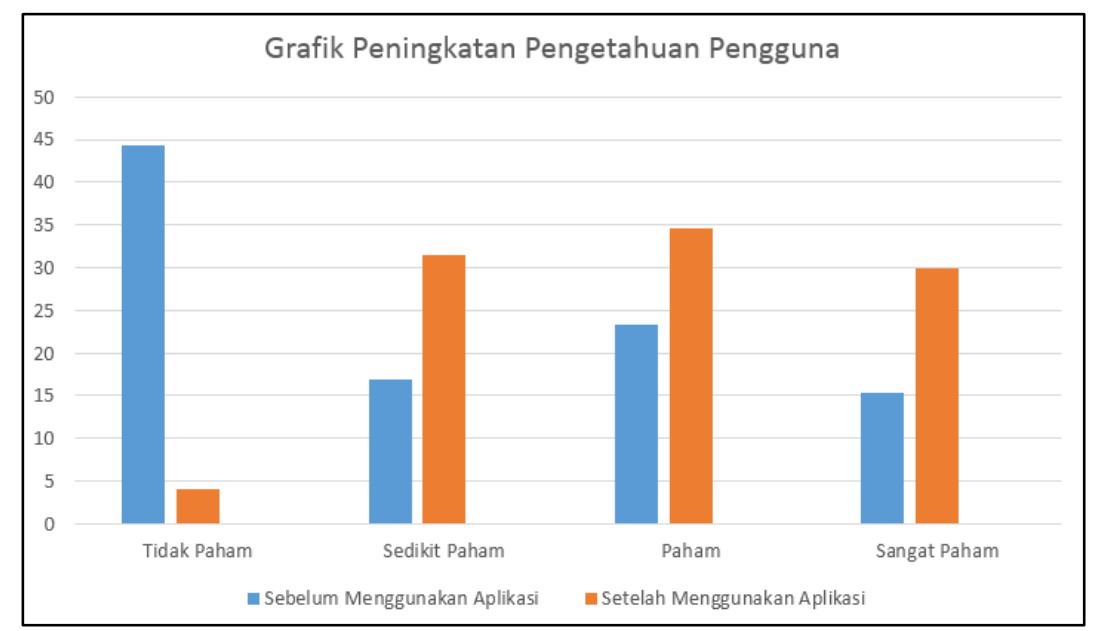




\section{Gambar 10. AspekPeningkatan Pengetahuan Pengguna}

Grafik peningkatan pengetahuan pengguna pada Gambar 10menunjukkan bahwa sebelum menggunakan aplikasi, banyak pengguna yang belum memahami metamorfosis dan belum mengetahui kupu-kupu langka, tetapi setelah menggunakan aplikasi, pengguna yang tidak paham sebanyak $40 \%$ berkurang menjadi $4 \%$. Pengguna yang sedikit paham, paham, dan sangat paham juga meningkat dari sebelumnya, sehingga dapat disimpulkan bahwa Aplikasi Pengenalan Jenis Kupu-Kupu Langka Berbasis Augmented Reality mampu meningkatkan pengetahuan siswa siswi kelas 4 SD tentang metamorfosis kupu-kupu dan jenis kupu-kupu langka sebanyak $36 \%$.

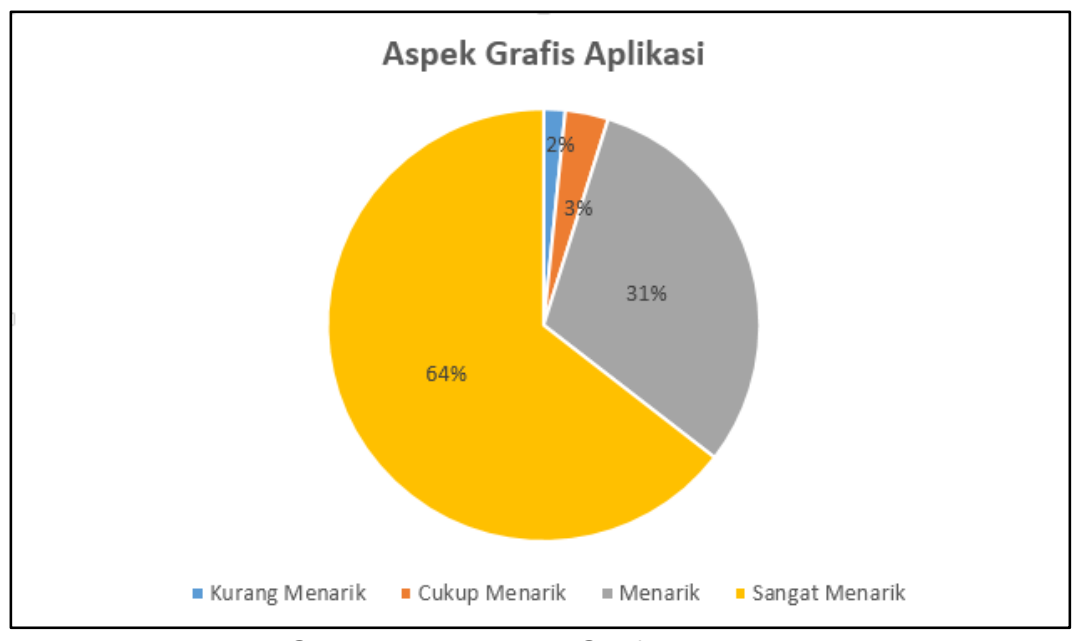

Gambar 11.Aspek Grafis Aplikasi

Responden memberikan respon kurang menarik sebanyak $2 \%$, respon cukup menarik dengan persentase $3 \%$, respon menarik dengan persentase $31 \%$, dan sangat menarik dengan persentase 64\%pada aspek grafis aplikasi. Persentase tertinggi terdapat pada pilihan sangat menarik yaitu $64 \%$, sehingga dapat disimpulkan bahwa aspek grafis aplikasi sangat menarik bagi pengguna.

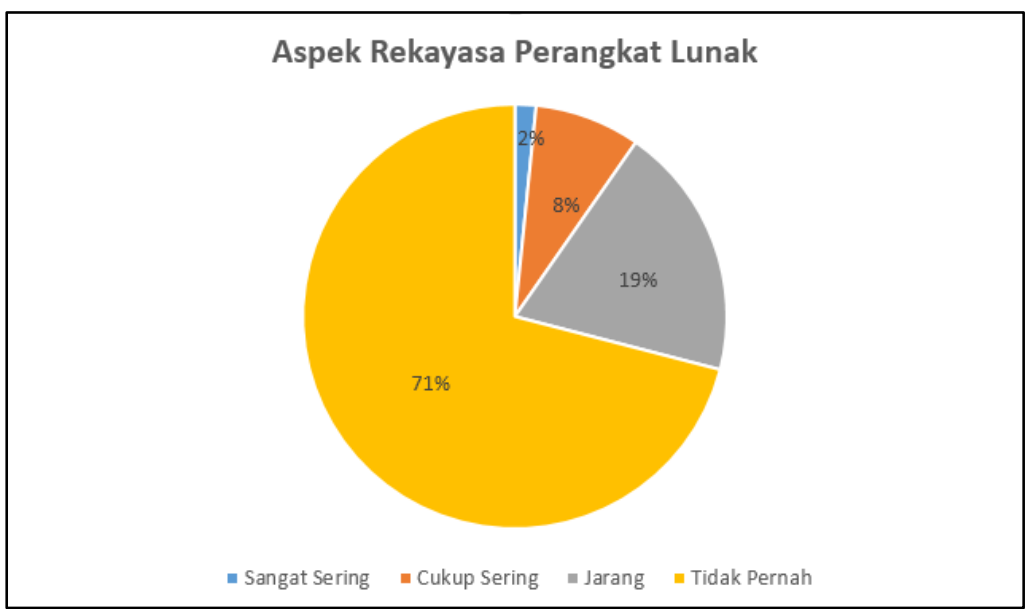

Gambar 12. Aspek Rekayasa Perangkat Lunak

Responden memberikan respon kurang menarik sebanyak $2 \%$, respon cukup menarik dengan persentase $8 \%$, respon menarik dengan persentase $19 \%$, dan sangat menarik dengan persentase $71 \%$ pada aspek rekayasa perangkat lunak. Persentase tertinggi terdapat pada 
pilihan sangat menarik dengan persentase $71 \%$, sehingga dapat disimpulkan bahwa aspek rekayasa perangkat lunak pada aplikasi sangat menarik bagi pengguna.

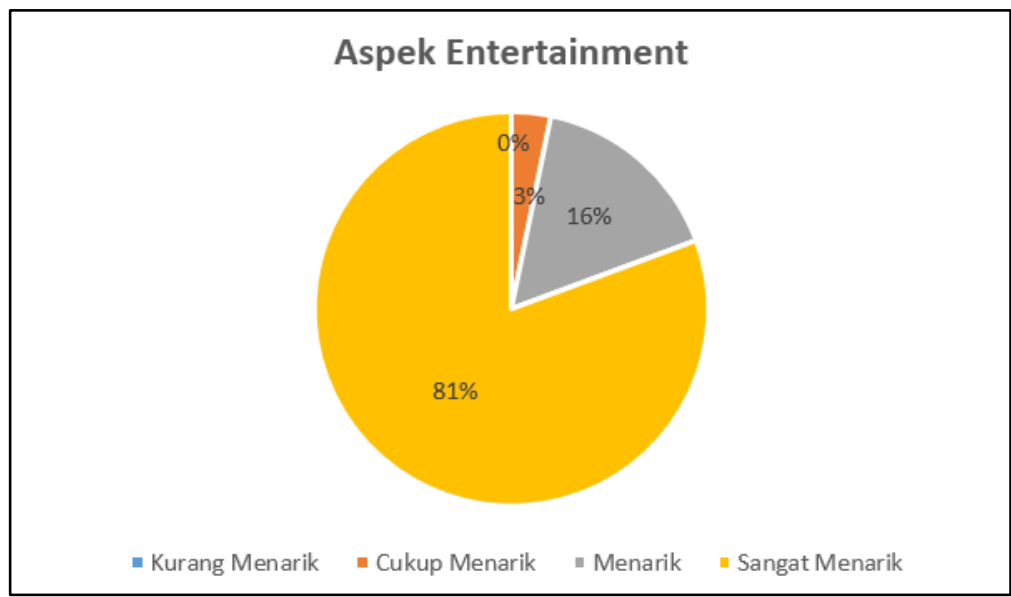

Gambar 13. Aspek Entertainment

Responden memberikan respon kurang menarik sebanyak 0\%, respon cukup menarik dengan persentase $3 \%$, respon menarik dengan persentase $16 \%$, dan sangat menarik dengan persentase $81 \%$ pada aspek entertainment. Persentase tertinggi terdapat pada pilihan sangat menarik dengan nilai $81 \%$, sehingga dapat disimpulkan bahwa aspek entertainment pada aplikasi sangat menarik bagi pengguna.

\section{Kesimpulan}

Aplikasi Pengenalan Jenis Kupu-Kupu Langka berbasis Augmented Realitydapat difungsikan secara dinamis, sehingga marker dan objek 3D dapat ditambah, diubah maupun dihapus tanpa harus melakukan modifikasi terhadap kode program aplikasi. Penilaian aplikasi dilakukan dengan menggunakan kuesioner yang ditujukan kepada siswa siswi kelas 4 SD. Aplikasi Pengenalan Jenis Kupu-Kupu Langka Berbasis Augmented Realitymampu meningkatkan pengetahuan tentang metamorfosis kupu-kupu dan jenis kupu-kupu langka sebanyak $36 \%$ berdasarkan kuesioner yang dilakukan. Hasil kuesioner lainnya yaitunilai sangat menarik sebanyak $64 \%$ pada aspek grafis aplikasi, nilai sangat menarik sebanyak $71 \%$ pada aspek rekayasa perangkat lunak, dan nilai sangat menarik sebanyak $81 \%$ pada aspek entertainment.

\section{Daftar Pustaka}

[1] B. Dewi, A. Hamidah, and J. Siburian, "Keanekaragaman dan Kelimpahan Jenis Kupukupu (Lepidoptera; Rhopalocera) di Sekitar Kampus Pinang Masak Universitas Jambi," Biospecies, vol. 9, no. 2, pp. 32-38, 2016.

[2] P. . Djunijanti Peggie, M. S., Precious and Protected Indonesian Butterflies. Jakarta: PT Binamitra Megawarna, 2011.

[3] I. D. Gede, W. Dhiyatmika, I. K. Gede, D. Putra, N. Made, and I. Marini, "Aplikasi Augmented Reality Magic Book Pengenalan Binatang untuk Siswa TK," Lontar Komputer., vol. 6, no. 2, pp. 589-596, 2015.

[4] N. I. Putu, S. Franza, and K. S. Wibawa, "APPLICATION OF BASIC BALINESE DANCE USING," Journal of Theoretical and Applied Information Technology., vol. 90, no. 1, pp. 61-66, 2016.

[5] A. Setiawan, I. P. Agus, and E. K. A. Pratama, "AUGMENTED REALITY FOR CHEMICAL ELEMENTS :," Journal of Theoretical and Applied Information Technology., vol. 90, no. 1, pp. 88-92, 2016.

[6] A. F. Waruwu, "Augmented Reality Mobile Application of Balinese Hindu Temples: DewataAR," I.J. Computer Network and Information Security., no. January, pp. 59-66, 
2015.

[7] I. G. A. Nugraha, I. K. Gede, D. Putra, and I. M. Sukarsa, "Rancang Bangun Aplikasi Augmented Reality Museum Bali Berbasis Android Studi Kasus Gedung Karangasem dan Gedung Tabanan," Lontar Komputer., vol. 7, no. 2, pp. 768-778, 2016.

[8] M. E. Apriyani, M. Huda, and S. Prasetyaningsih, "Analisis Penggunaan Marker Tracking Pada Augmented Reality Huruf Hijaiyah," Jurnal Infotel., vol. 8, no. 1, pp. 71-77, 2016.

[9] S. Kasus, P. Bendera, H. Majapahit, B. Sihite, F. Samopa, and A. Sani, "Pembuatan Aplikasi 3D Viewer Mobile dengan Menggunakan Teknologi Virtual Reality," Jurnal Teknik Pomits., vol. 2, no. 2, pp. 397-400, 2013.

[10] I. K. Y. Mariyantoni and P. N. Crisnapati, "Gamelan Bali," Jurnal Nasional Pendidikan Teknik Informatika (JANAPATI)., vol. 3, pp. 21-28, 2014. 